\title{
"Internet + Tourisim" promotes the research on the inheritance and development of Jinan spring culture
}

\author{
Xiangli Dong* \\ School of Computer Science, Shandong Xiehe University, Shandong, China
}

\begin{abstract}
With the rapid development of Internet technology, "Internet +" has enabled the development of tourism and helped the transformation and upgrading of tourism. Cultural tourism is having a profound impact on cultural inheritance and development. This paper aims to promote Ji 'nan Spring Culture to move towards the direction of smart tourism by the deep integration of "Internet + Tourism". Discuss reasonable and feasible inheritance, development and protection strategies. To solve the problems existing in the development of Spring Culture and tourism, protect and inherit the features of Spring Culture, and promote the orderly and healthy development of Spring Culture in Jinan.
\end{abstract}

Keywords: Internet +, Tourisim, Spring culture.

\section{Introduction}

With the development of society, the new generation of information technology based on the Internet develops rapidly. With the continuous and rapid growth of "Internet + Tourism", cyberspace has become a new space for people's production and life. It is also a new space for us to build consensus on the promotion of traditional culture through tourism. It is the main front for the promotion of traditional culture at present. Mobile Internet, in particular, has become the main channel of cultural communication.[1] Culture and the Internet have a natural affinity and integration.With the arrival of more and more mass tourism, personalized tourism, information tourism, leisure tourism and social tourism, we have made full use of the Internet Plus Tourism to provide cultural guidance and ideological guidance, carry forward cultural heritage, and serve the people, demonstrating great resilience and development potential. Let technology empower tourism, add "wisdom core" to tourism, let culture carry the wings of tourism, promote the integration of science and technology, culture and tourism, and accelerate the high-quality development of Quan cultural tourism.

*Corresponding author: 778118795@qq.com 


\section{A brief introduction to spring culture}

Lotus flowers on all sides, willows on three sides,[2] a city of mountains and half a city of lakes, Jinan, also known as Quancheng, is the capital city of Shandong Province. It is the political, economic, cultural, scientific and technological, educational and financial center and an important transportation hub of Shandong Province.[3]Rich in cultural resources, cultural industry foundation is strong. Spring water is the soul of Jinan and the name card of Jinan in the world. The reasons for the formation of Ji 'nan spring are different in ancient times. According to the investigation and research of modern geologists, Ji 'nan spring comes from the mountainous area in the southern part of the city. The atmospheric precipitation seeped underground and flowed northward along the inclined direction of the rock strata.[4]Geological structure, seasonal rotation and precipitation change all affect the dynamic change of spring water. There are a large number of underground springs in Jinan, which are concentrated in distribution and have a unique style. There are a large number of underground springs in Jinan, which are concentrated in distribution and have a unique style. Literati and calligraphers of all dynasties are fascinated by them. There are countless poems and poems in praise of springs and anecdotes passed down from generation to generation. Spring water resources unique, pure taste sweet water, containing a variety of trace elements beneficial to human body. Spring water resource is high quality drink water source. In ancient times, rivers and lakes formed a water network, which facilitated the transportation of Jinan. In the development of modern cities, although the sources of water are diversified, springs are still an important source of water for Jinan residents. Close to the spring, people wash rice and wash clothes here. In order to drink the spring water from a long distance, people do not hesitate to trek a long way, and they are also very happy to pull a car or carry it on their shoulders. The city nourished by the spring gives birth to countless heroes. In addition to providing water for human beings, Jinan spring water has also provided ornamental value and gradually evolved into a unique spring water culture. It is the most precious cultural heritage and wealth of Jinan, and also a wonderful flower in China's excellent national culture. On June 8, 2019, Ji 'nan Quan · City Cultural Landscape was officially listed on the preparatory list of China's World Cultural Heritage, making the spring culture go out of the country to the world.[5]With profound and unique spring water culture, Jinan has also become a famous historical and cultural city, second to none in the world.

\section{The significance of realizing the inheritance and development of spring water culture under the background of "Internet + Tourism"}

Jinan is alive with spring water, jinan is pregnant with beauty and productive of talent with spring water. The culture of spring water is the culture of Jinan city, with rich connotation, long history and profound accumulation, but there is still a lot of room for excavation. Let more cultural elements extend in, let more citizens, tourists and scholars have a deep understanding of spring culture. To protect the spring is to protect the culture of Jinan and maintain the characteristics of the spring city. "Internet + " represents a new economic form, and a kind of hard power, which promotes the integration of tourism, culture and science and technology. The combination of "Internet + tourism" and cultural soft power will play a huge role and form new industries. Nowadays, with the rapid development of "Internet + tourism", it is of great significance and value to carry out effective inheritance, development and promotion of Jinan Spring Culture. 


\subsection{Theoretical meaning and value}

Through the perspective of "Internet + Tourism", the connotation of Quan culture is deeply explored, and the theoretical system of Quan culture and tourism is enriched. It provides new practical directions for smart tourism, new ideas for the inheritance and innovative development of Jinan Spring culture, and new driving forces for the high-quality development of cultural and tourism integration.

\subsection{Practical significance and value}

Spring is the world business card of jinan, the spring culture is the culture of jinan city, it is the city of the soul, and it is a crowd of outstanding national culture in our country. Through the perspective of "Internet + Tourism" text brigade fusion better improve spring culture in the country or the world brand, improve the spring culture awareness in people's minds, enhance the consciousness of spring protection to protect springs. It has important value of the urban construction and spiritual heritage value, in carrying forward national culture spirit, in developing modern cultural industry, in enhancing China's cultural soft power.

\section{Inheritance and development status of Jinan spring culture in the era of "Internet + Tourism"}

\subsection{Inheritance and development status of Jinan spring culture}

In recent years, production and living wastewater pollution, large-scale commercial and industrial development have led to the discoloration of spring water, people's overuse of spring water, and drought caused by climate change, making many springs in Jinan face a crisis. With the advent of modernization, the city develops with great enthusiasm, with many buildings and crowds pouring out. People seem to only stay on the symbol of Quan Jiajia Tianxia. Not only many citizens, especially young people including tour guides, lack a systematic understanding of Spring Culture in Jinan, or even know little about it, which is a pity. Some scholars have less professional research on Ji 'nan Spring Culture. When they search the keywords of Ji 'nan Spring Culture on the China National Knowledge Network (CNKI), there are only a few relevant research papers. Without the in-depth study of theory, how to do a good job in professional publicity, how to design spring culture characteristic tourism products, how to attract more people to travel, Ji 'nan spring culture to be publicized.

\subsection{Current situation of cultural tourism development}

Tourism is not only an important driving force for economic development, but also an important field for promoting social harmony, an important carrier for cultural construction and an important link for cultural exchanges. Cultural and tourism industry is highly dependent on external environment and weak in risk resistance. The COVID-19 epidemic in 2020 has an unprecedented impact on the cultural and tourism industry in China and even the world, which has been affected to varying degrees and is facing challenges in promoting cultural inheritance and development through tourism. However, challenges and opportunities exist side by side. The Ministry of Culture and Tourism, the National Development and Reform Commission and other 10 government departments jointly issued the Opinions on Guidelines on Deepening the Internet Plus Tourism Initiative to Promote 
High-quality Development of Tourism, proposing to optimize the business environment of "Internet + tourism" and promote the high-quality development of tourism with digital empowerment.[6]At present, the continuous updating and iteration of modern information technology, represented by the Internet, has provided a strong impetus for the high-quality development of tourism. Tourism has now become people's rigid consumption, and the trend of tourism promoting cultural inheritance and development will not change. When the epidemic is over, the rigid demand will rebound strongly.[7]

\section{The opportunities and challenges facing the inheritance and development of $\mathrm{Ji}$ 'nan spring culture}

The COVID-19 epidemic has brought both challenges and opportunities to the development of the cultural tourism industry. Seize the opportunity, attach importance to the inheritance and development of Spring Culture, and make Spring Culture more accurate and faster to "fly into the homes of ordinary people". With the help of advanced information technology, we can inherit, develop and protect spring culture through innovative strategies, jointly cherish and care for this gift of nature, and construct a development strategy suitable for spring culture in Jinan under the background of "Internet + tourism". Specific strategies are as follows.

\subsection{Strengthen cultural education and enhance cultural awareness}

Strengthen people's cultural education, enhance cultural awareness, and strengthen cultural confidence. Spring culture education is regarded as an important part of excellent traditional Chinese culture education, and it is organically integrated into cultural activities or curriculum materials by combining the cognitive development characteristics of people of different ages. With the help of virtual simulation, holographic projection and other hightech perfectly present the value and charm of Spring Culture, imperceptibly accept the influence and infiltration of Spring Culture, and gradually generate the cognitive identity of Spring Culture. It is no longer one-way communication in the traditional sense, but pays more attention to interactive communication. They can give full play to their autonomy, express their opinions according to their own understanding and comprehension, and spread what they have learned through thumb up, forwarding microblog WeChat circle of friends, so that more people can see it.

\subsection{Dig deeply the cultural connotation, and promote the revitalization of the cultural tourism industry}

We should give full play to the leading role of "Internet + Tourism", promote the deep integration of the Internet, big data, artificial intelligence and tourism, and the organic integration of cultural elements and scientific and technological content will play a huge role. Make full use of the existing Quan product resources, through optimization, transformation and upgrading, add light and color to the Spring Culture brand, and then dig deeply into the connotation of Ji 'nan Spring Culture, such as historical connotation, humanistic connotation, etc., shape and strengthen the Spring Culture brand, and expand the space for the inheritance of Ji 'nan Spring Culture. Promote the transformation and upgrading of the tourism industry, constantly open up new tourism markets, and promote the revitalization of the cultural and tourism industry. 


\subsection{Optimize spring culture transmission system, strengthen regional infrastructure construction, innovate marketing mode}

In the post-epidemic era, cultural tourism should adopt new thinking, new models and new drivers, adhere to scientific and technological innovation, and upgrade smart tourism.[8] Normalized epidemic prevention and control requires reducing direct human contact and avoiding crowd gathering. In order to optimize Spring Culture communication system, it is necessary to strengthen regional infrastructure construction, break through bottlenecks, overcome technical barriers, innovate tourism models, stimulate Spring Culture innovation and creation vitality through digitalization, advance online and offline simultaneously, deeply integrate culture and science and technology, and promote the development of smart tourism. Information dissemination has become the mainstream way, information is everywhere, omnipresent, no one does not use, not subject to time, place, environment and other aspects of the restrictions, fast access, real-time update. By providing personalized services through data, the digital tourism economic system represented by Internet technology is constructed. Mobile phone terminals and other communication devices are used to realize the innovation and improvement of marketing mode, increase online marketing efforts, enhance online customer acquisition ability, and strengthen the interaction with fans. We can also use the current widespread live video broadcast mode to narrow the sense of distance in the space of tourists. Bring tourists more fresh visual experience and immersive feeling. The virtual simulation technology and holographic projection method are used to construct the new scene of Spring Culture experience. At the same time, strengthen tourism supervision services, enhance tourism governance ability, and ensure the security of tourism data. It can also support tourism innovation and entrepreneurship, promote the innovation and development of Jinan spring culture in the fields of cultural inheritance, cultural exhibition and product circulation with the help of tourism, improve the economic benefits of Jinan spring tourism, and improve the soft power of Jinan culture.

\section{Conclusion}

Today, with the rapid development of media communication and Internet technology, the form of communication integrates the emerging power of communication. Mainstream media, new media platform push, online and offline collaboration. The integration and indepth excavation of Spring Culture in Jinan will help to broaden the communication channels of Spring Culture and spread the good voice of traditional culture louder and farther in the new era. Spare no effort to preserve the precious legacy of our ancestors and nature.

The key subject of art science in shandong province: "Internet + tourism" promotes the research on the inheritance and development of Jinan spring culture (ZD202008429).

\section{References}

1. The Chinese net letter.Self-statement of Xi Jinping: "My" Internet thinking[EB/OL].http://news.hnr.cn/rmrtt/article/1/1354341046783447040,2021-1-27.

2. Weiqing Yan."Lotus on four sides and willow on three sides, a city with mountains and half a city lake"__ Jinan in The Travels of Old Disabled Man[J].Literature and history knowledge.1987(10):101-104. 
Municipal

People's

Government.Jinan overview.http://www.jinan.gov.cn/col/col129/index.html,2020-07-22.

4. Jinan

MingQuan.Spring

water causes[EB/OL].http://www.jnlib.net.cn/newmq/mq_gl11.html.

5. Dongyang Li.The cultural landscape of Ji 'nan Quan - City has been included in the preparatory list of China's world cultural heritage![N].Jinan daily,2019-06-08.

6. Ministry of Culture and Tourism, PRC.Guidelines on Deepening the Internet Plus Tourism Initiative to Promote High-quality Development of Tourism[EB/OL].http://zwgk.mct.gov.cn/zfxxgkml/zcfg/zcjd/202012/t20201205_9154 94.html,2020-11-30.

7. The Chinese government net.Guidelines on Deepening the Internet Plus Tourism Initiative to Promote High-quality Development of Tourism[EB/OL].http://www.ce.cn/culture/gd/202012/25/t20201225_36158398.shtml. 2020-12-05.

8. Wen brigade China."Butterfly Change" of Tourism Industry Innovation Enabled by Science and Technology[EB/OL].Surging news.https://www.thepaper.cn/newsDetail_forward_10433978,2020-12-17. 